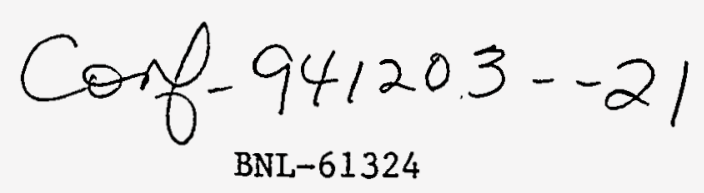

\title{
HEALTH AND ENVIRONMENTAL HAZARDS OF CdTe PHOTOVOLTAIC MODULE PRODUCTION, USE AND DECOMMISSIONING
}

\author{
Paul D. Moskowitz, Brookhaven National Laboratory, Upton, NY 11973, USA \\ Hartmut Steinberger, Fraunhofer Institut fur Festkorpertechnologie, W-80685 Munchen, Germany \\ Werner Thumm, GSF-Institute of Ecological Chemistry, D-85758 Oberschleissheim, Germany
}

\begin{abstract}
Health and environmental (H\&E) risks presented by CdTe photovoltaic module production, use and decommissioning have been reviewed and discussed by several authors. Several H\&E concerns exit. The estimated risks are based on extrapolations of toxicity, environmental mobility, and bioavailability data for other inorganic cadmium compounds. Little information, however, is available about CdTe itself. In response to the increased interest in CdTe, Brookhaven National Laboratory (BNL) has been engaged in a cooperative research program with the National Institute of Environmental Health Sciences (NIEHS), the Fraunhofer - Institute for Solid State Technology (IFT), and the GSF Institute of Chemical Ecology to develop fundamental toxicological and environmental data for CdTe. This paper describes the results of these studies, and their potential implications with respect to the H\&E hazards presented by CdTe module production, use and decommissioning.
\end{abstract}

\section{Introduction}

Health and environmental (H\&E) risks presented by CdTe photovoltaic module production, use and decommissioning have been reviewed and discussed by several authors $[1,2]$. Several H\&E concerns exit. The estimated risks are based on extrapolations of toxicity, environmental mobility; and bioavailability data for other inorganic cadmium compounds. Little information, however, is available about CdTe itself. In response to the increased interest in CdTe, Brookhaven National Laboratory (BNL) has been engaged in a cooperative research program with the National Institute of Environmental Health Sciences (NIEHS), the Fraunhofer Institute for Solid State Technology (IFT), and the GSF Institute of Chemical Ecology to develop fundamental toxicological and environmentak data for three compounds (CIS, CGS, and CDTe) of interest to the photovoltaics community. This paper describes the results of these studies for CdTe, and their potential implications with respect to the H\&E hazards presented by CdTe module production, use and decommissioning.

\section{Chemical and Physical Properties}

Cadmium telluride (CdTe) is a black, dense cubic, crystalline compound that does not occur naturally. Cadmium telluride is insoluble in water, however, it decomposes on exposure to atmospheric moisture with the evolution of gaseous hydrogen telluride $\left(\mathrm{H}_{2} \mathrm{Te}\right)$, a toxic, volatile acid that is very soluble in water. The presence of acios or acid fumes accelerates this decomposition. Under very dry conditions the compound will react with atmospheric oxygen to form oxides of cadmium and tellurium. It is unlikely, therefore, that the unencapsulated compound will persist for long periods of time as CdTe under natural soil conditions or within landfills. Reaction with $\mathrm{H}_{2} \mathrm{O}$ and $\mathrm{O}_{2}$ will lead to the decomposition of the compound and the release of new $\mathrm{Cd}$ and $\mathrm{Te}$ compounds and ions into the environment.

\section{Toxicological Properties}

No human clinical data are available on the potential health effects associated with exposure to CdTe. in the absence of human data, animal data are used by regulators to assess potential health hazards presented by chemicals used in commerce or found in the environment. At the request of BNL and others, the NIEHS National Toxicology Program studied the systemic and reproductive toxicity of CdTe in rats. In these studies rats were exposed to CdTe present in their food for a 28 day period. After the 28 days, the rats were sacrificed and clinical signs, inciuding in-life-body weights, termınas body weights and organ weights, histology, clinicas chemistry, and hematology were evaluated. The studies. published elsewhere in greater detail [3], suggest unat CdTe did not consistently cause adverse effects at the dosage levels evaluated; these dosage levels. are orders of magnitude higher than the dosage that would $\infty$

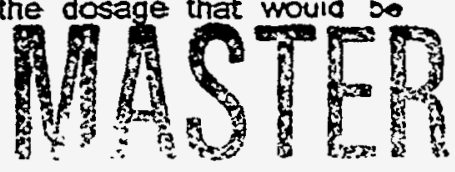

This research was performed under the auspices of the United States Department of Energy under Contract No. DE-ACO2-76CH00016 
allowed under current U.S. Environmental Protection Agency (EPA) or Occupational Safely and Health Administration (OSHA) regulations. These studies also indicated that at the dosage levels tested, CdTe did not produce adverse reproductive or developmental toxicity.

Harris et al. [3] speculated that since no vascular, renal or teratologic damage was seen (indicative of cadmium poisoning), circulating blood levels of cadmium were low. The normal urinary $\mathrm{Cd}$ and protein values observed in the study support this conclusion. Additional studies are underway to measure levels of cadmium in blood and tissues in the animals used in the Harris et al. study and in other studies that used inhalation as the route of exposure. Cadmium is poorly absorbed by oral administration, and CdTe is virtually insoluble in aqueous solutions. Therefore, the CdTe may not be biologically available by this exposure route. Since occupational exposures are more likely to cocur through inhalation or dermal absorption, not ingestion as was mimicked in these laboratory studies, caution must be exercised in extrapolating these findings to occupational settings. Further, other limitations exist including the short-term nature of these studies; plans are now being made to expand the scope of these studies to fill these gaps. Nevertheless, these initial studies suggest that CdTe may not be as toxic as other inorganic cadmium compounds.

\section{Environmental Studies}

At the GSF in Munich, Germany, studies are being conducted to develop physical-chemical data that could be used to evaluate the environmental mobility (i.e., transport through air, water, soil and biological organisms) of CdTe and by-products released during the combustion of CdTe modules in fires (e.g., building or incinerators) and during decay in landfills where manufacturing wastes and spent modules could be placed at the end of their useful life.

Module behavior in fires is mimicked by using moderm thermo-analytical techniques. Results of a differential thermal analysis for pure CdTe are shown in Fig. 1. In air, the experiments showed that there was an increase in weight until about $750-800^{\circ} \mathrm{C}$.; this is possibly due to oxidation. This oxidized product remains stable until about $1050^{\circ} \mathrm{C}$. At higher temperatures, the compound begins to evaporate. The higher temperatures where material evaporation was observed are representative of the conditions present in a large municipal solid waste incinerator.

Module behavior, including metals leachability in landfills, is being characterized by two different elution tests: the EPA Toxicity Characterization Leachate Profile (TCLP), and the German DEV S4. In these tests, small $\left(<1 \mathrm{~cm}^{2}\right)$ pieces of a broken CdTe module are suspended and rotated in an elutent for 24 hours. The metals present in the elutent are then measured and compared with limits prescribed by each testing protocol. If the metal concentration in the elutent exceeds the limits, the modules are demonstrating metal leachability and may need to be recycled or disposed of in a hazardous waste landfill. if the metals are not leaching in excessive quantities the modules can be disposed of in a commercial landfill like many other consumer products. Tables 1 and 2 display the results of these tests for a $\mathrm{CdTe}$ photovoitaic module. To the extent that these data are representative of CdTe modules to be sold in the market place, spent and decommissioned modules might need to be treated as hazardous waste. More testing is required to confirm this conclusion. If this conclusion is correct, it will be important to develop cost-effective recycling strategies.

\begin{tabular}{|l|l|l|l|}
\hline \multicolumn{3}{|l|}{ Table 1. EPA TCLP Leach Testing Results $(n=4)$} \\
\hline \multicolumn{1}{|l|}{} & \multicolumn{2}{|c|}{ TCLP } \\
\hline $\mathrm{Cl}$ dement & Results & Existing & Proposed \\
\hline $\mathrm{Te}$ & $1.53 \pm 0.21$ & 1.0 & 0.91 \\
\hline $\mathrm{Al}$ & $0.47 \pm 07$ & & \\
\hline $\mathrm{Ni}$ & $1.26 \pm 0.14$ & & \\
\hline
\end{tabular}

\begin{tabular}{|l|l|l|l|}
\hline \multicolumn{4}{|l|}{ Table 2. German DEV S4 Leach Testing Results $(n=4)$} \\
\hline \multicolumn{1}{|c|}{ Element } & Results & 1 & \multicolumn{2}{|c|}{ Class } \\
\hline $\mathrm{Cd}$ & $0.50 \pm 0.13$ & 0.05 & 0.19 \\
\hline $\mathrm{Te}$ & $0.50 \pm 0.13$ & & \\
\hline $\mathrm{Al}$ & $0.87 \pm 0.20$ & & \\
\hline $\mathrm{Ni}$ & $0.25 \pm 0.04$ & 0.2 & 1 \\
\hline
\end{tabular}

\section{Industrial Hygiene Studies}

In parallel with these experimental studies, BNL [4] has assembled industrial hygiene monitoring data from the photovoltaic industry. Because there is little published information on the monitoring of employee exposures in CdTe manufacturing of photovaltaic cells, we relied or personal communications $[5,6]$. These personal communications from an industrial hygienist at the National Renewable Energy Laboratory reveal that no detectable levels of cadmium were reported from personal monitoring of maintenance operations (CdTe physical vapor deposition system and CdTe over overhaul), daily operations in physicat vapor deposition, or sandlbasting cadmium target operations [5]. However, area samples taken in line with exhaust flow during the maintenance of the physical vapor deposition system were measured at $30 \mathrm{ug} / \mathrm{m}^{3}$; this is above the OSHA 
action level of $2.5 \mathrm{ug} / \mathrm{m}^{3}$. Initial wipe samples taken in the deposition and sample preparatory laboratories ranged from below detection to $0.59 \mathrm{mg}$, but dropped below detectable levels after good housekeeping procedures were established. Wipe samples in the physical vapor deposition laboratory ranged from 1.7 - 92 ug.

At a pilot scale CdTe module production facility, personal samples were collected from the sandblasting/buffing operation, laser scribing room, and chemical treatment room [6]. There were no exposures to cadmium above the current OSHA action level of 2.5 $\mathrm{ug} / \mathrm{m}^{3}$. Area sampling found non-detectable levels of cadmium within and outside the cell production area (e.g., lunch room, module chemical treatment rom center of work area, analytical laboratory, and laser room). Wipe samples ranged from a low of $0.0038 \mathrm{mg}$ (secretary's desk) to a high of $2.4 \mathrm{mg}$ within the work area. Unadjusted urinary cadmium levels from the workers at this same facility ranged from 0.2-0.9 ug $\mathrm{Cd} / \mathrm{L}$ urine; this is well below the threshold limit of $5 \mathrm{ug} C \mathrm{~d} / \mathrm{L}$ established by the American Conference of Governmental and Industrial Hygienists.

The literature contains limited industrial hygiene monitoring information on other semiconductor production processes; this literature is important because of some insights it provides. Ungers et al. [7] determined that arsenic can be released from freshly ion-implanted silicon wafers, manufactured under high vacuum conditions $\left(10^{-6}\right.$ torr). Although information is available about the behavior of dopant atoms on the crystal lattice of the substrate, there are little data on dopant atoms in the crystal lattice of the substrate, and nothing about the fate of atoms associated with this superficial deposition. The theory that these atoms diffuse out of the wafer and are released to the environment gained support from workers' complaints of odors in wafer-handling operations near the ion-implanter station. Odor problems have also been reported in CdTe and other photovoltaic thin-film production facilities [8-10]. The implication of these findings is that there is potential for metais accumulation in the air in any facility where modules are stored prior to encapsulation and the rooms are poorly ventilated.

\section{Discussion/ and Conclusions}

There is large interest and need to characterize, in a realistic fashion, the H\&E risks presented by CdTe photovoltaic module production, use and decommissioning. This interest is fueled by the existing H\&E regulations that focus on other inorganic cadmium compounds and the-increasing investments being. made to develop large-scale CdTe module manufacturing facilities. Arguments to date about the actual risks presented by CdTe have been based on the extrapolation of H\&E data from other cadmium compounds and related industries. The experimental data developed for this project and the industrial hygiene observations collected from existing CdTe facilities suggest that the actual H\&E risks from CdTe module production and use are smaller than a simple hazard analysis would suggest. Nevertheless, because of the inherent toxicity of the parent compounds, an ongoing effective industrial hygiene program is needed to ensure that workers' health is not compromised. Furthermore, recycling strategies for waste products from CdTe manufacturing facilities and spent modules may also be needed to protect public health and facilitate the marketing of these devices.

\section{References}

1. Moskowitz, P.D., 1992. Environmental, Health and Safety Issues Related to the Production and Use of CdTe Photovoltaic Modules. International Journal of Solar Energy, Vol. 12, pp. 259-281 (1992). BNL 47372, Upton, NY.

2. Patterson, M., A.K. Turner, M. Sadeghi, and R.J. Marshall, 1994. Health, Safety and Environmental Aspects of the Production and Use of CdTe Thin Film Photovoltaic Modules. 'Presented at the 12th EC PVSEC, The Netherlands.

3. Harris, M.W., et al., 1994. The general and reproductive toxicity of the photovoltaic material cadmium telluride (CdTe). Presented at the Society of Toxicology 1994 Annual Meeting, Dallas, Texas, March 13-17, 1994. The Toxicologist `4:267, 1994.

4. Bernhoic, N., P. Moskowitz, R. Chapin and M. Harris, 1994. "Cadmium telluride - summary report on industrial hygiene," in P.D. Moskowitz and K Zweibel, Editors, "Understanding and Managing Health and Environmental Risks of CIS, CGS, CdTe Photovoltaic Module Production and Use: A Workshop Report. Brookhaven National Laboratory, Upton, NY.

5. Donley, J.,1994. Personal communication, National Renewable Energy Laboratory, Golden, Colorado.

6. Meyers, P., 1994. Personal communication, Solar Cells, Inc., Toledo, Ohio.

7. Ungers, LJ., J.H. Jones, A.J. Mcintyre, and C.R. McHenry, 1985. Release of arsenic from semiconductor wafers. Am. Ind. Hyg.Assoa J. 46(8):415-420.

8. Luke, D., 1993. Personal communication, National Renewable Energy Laboratory, Golden, Colorado.

9. Mosier, W., 1994. Personat communication, Martin Marietta, Denver, Colorado. 
10. Gay, R., , 1994. Personal communication, Siemens

Solar Industries, Camarillo, California.

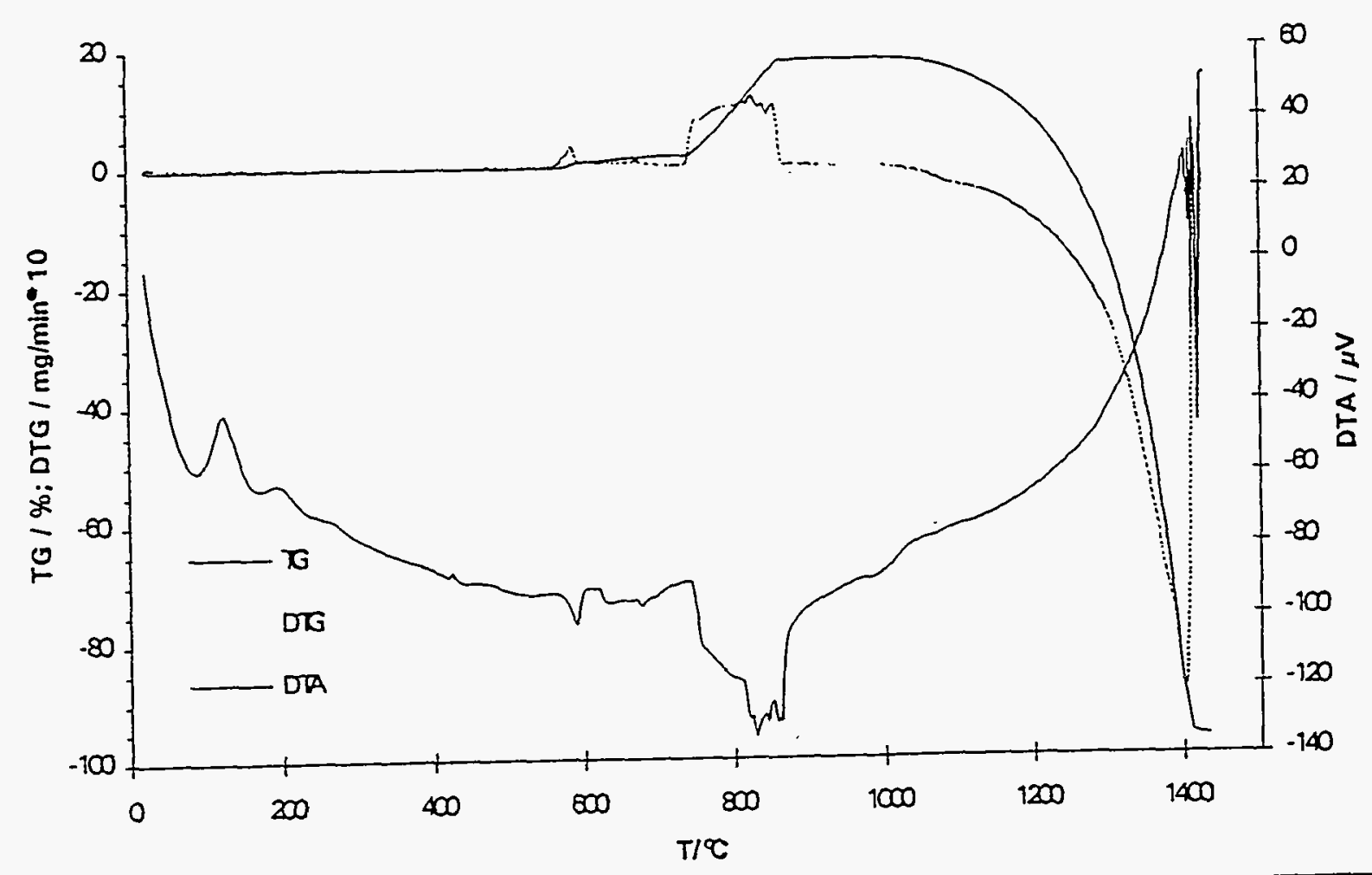

Fig. 1. Differential thermal analysis of pure CdTe in air.

\section{DISCLAIMER}

This report was prepared as an account of work sponsored by an agency of the United States Government. Neither the United States Government nor any agency thereof, nor any of their employees, makes any warranty, express or implied, or assumes any legal liability or responsibility for the accuracy, completeness, or usefulness of any information, apparatus, product, or process disclosed, or represents that its use would not infringe privately owned rights. Reference herein to any specific commercial product, process, or service by trade name, trademark, manufacturer, or otherwise does not necessarily constitute or imply its endorsement, recommendation, or favoring by the United States Government or any agency thereof. The views and opinions of authors expressed herein do not necessarily state or reflect those of the United States Government or any agency thereof. 


\section{DISCLAIMER}

Portions of this document may be illegible in electronic image products. Images are produced from the best available original document. 